\title{
The best interest of the child as an argument in assessments of parent potential in Sweden
}

\author{
Judith Lind
}

\section{Linköping University Post Print}

N.B.: When citing this work, cite the original article.

This is a pre-copy-editing, author-produced PDF of an article accepted for publication in International Journal of Law, Policy and the Family following peer review. The definitive publisher-authenticated version is available online at:

Judith Lind, The best interest of the child as an argument in assessments of parent potential in Sweden, 2008, International Journal of Law, Policy and the Family, (22), 1, 1-21.

http://dx.doi.org/10.1093/lawfam/ebm014

Copyright: Oxford University Press (OUP): Policy E http://www.oxfordjournals.org/

Postprint available at: Linköping University Electronic Press http://urn.kb.se/resolve?urn=urn:nbn:se:liu:diva-75850 
Judith Lind

Department of Child Studies

Linköping University

Sweden

judar@tema.liu.se

The best interest of the child

as an argument in assessments of parent potential in Sweden

\begin{abstract}
This paper examines the ways in which the best interest of the child has been used as an argument for state-authorized assessments of persons who are aspiring to parenthood, but who are not yet parents, i.e. of parent potential rather than parental performance. The policies included in the analysis concern three different areas in which assessment of parental potential is made: adoption, assisted reproduction and presumptive parents with intellectual disabilities. The status of the best interest of the child as an argument for state-authorized assessments of parent potential, I argue, varies with the amount of involvement from state authorities that is needed in the process of creating a family. The state claims the right to assess the parent potential of individuals only when it contributes to the creation of families in which there are no or only partial biogenetic links between parents and child. This does not mean that the state does not aim to encourage women who belong to what is perceived as a risk group to refrain from having children. The argument used in this effort, however, is not the best interest of the child, but the best interest of the woman herself.
\end{abstract}




\author{
Judith Lind \\ Department of Child Studies \\ Linköping University \\ Sweden \\ judar@tema.liu.se
}

\title{
The best interest of the child as an argument in assessments of parent potential in Sweden
}

\section{Introduction}

The state's interest in and obligation to protect its children's welfare is widely recognized in many nation-states of today. This means that, in many instances, the state has taken on the role as guarantor of the best interest of the child - if necessary, in conflict with the child's parents. If care provided by the parents jeopardizes the well-being of a child, state interventions are regarded not only as acceptable, but as called for.

Even when parental rights are described as fundamental and as entitled to heightened protection through state regulation, in some cases state intervention is argued to be the only way to protect the best interest of the child. ${ }^{1}$ The best interest of the child, thus, constitutes the only argument that can be used to motivate encroachment on the family. The exploitation of internal conflicts within the family has, according to Donzelot (1980), frequently been used to legitimate interventions in family life, in which agencies and states have allied themselves with weaker family members.

Naturally, state intervention in family life can take many forms: laws and regulations concerning parental leave, corporal punishment, parents' right to choose schooling for their children, but also interventions in individual families and the separation of individual children from their parental homes. In no other case than the latter is reference to the best interest of the child more crucial. The fundamental status of the family reflects the presumption that a 
child's best interest lies in remaining with her birth parents. And because of the strong tendency to preserve family integrity, it is generally required that the unfitness of the parents be proved through individual inquiry before the child is taken into custody or parental rights are terminated.

This paper aims at examining the ways in which the best interest of the child has been used as an argument for state intervention in family life in situations where parental abilities to meet the child's needs have been under assessment. The policies included in the analysis concern three different areas in which assessment of parental abilities are made: adoption, assisted reproduction and intellectual disabilities and parenthood. What these assessments have in common is that they concern parent potential rather than parental performance, i.e. they are assessments of persons who are not yet parents, but who are aspiring to parenthood.

By discussing several different areas of state intervention in family life and the creation of families, I hope to contribute to a wider understanding of the role that the best interest of the child has played as an argument in family policies. The empirical material includes legislation, parliamentary reports, official policies and recommendations issued by the Board of Health and Welfare (Socialstyrelsen) and the Board on International Adoptions (Nämnden för Internationella Adoptioner (NIA); now Myndigheten för Internationella Adoptioner (MIA)).

\section{Risk factors and risk groups}

Official definitions of parental unfitness are usually vague. One example is the American statutes on the termination of parental rights. Although they do identify various factors to consider, these factors tend to be imprecise. They focus on neglect in providing such necessities as food, shelter or medical care and on physical, sexual and emotional abuse. This means that they focus on how the parents have performed, i.e. what they have done or failed 
to do. However, the statutes also include mental illness and developmental disability as factors to consider (Watkins 1995). In contrast to the factors focusing on neglect and abuse, illnesses and disabilities do not necessarily require consideration of an individual inquiry into the parent's performance.

Several Swedish studies as well as studies from other countries have shown that in many child protection cases, mental illness and intellectual disabilities are presumed to imply the inability to care for children. They have also shown that, in situations where a whole range of problems is at hand, including poverty, lack of familial support or domestic violence, what is often regarded as the main, and irredeemable, cause of parental inadequacy are the intellectual disabilities of the parent(s). As a consequence, parents with intellectual disabilities are far more likely to appear in child protection and parental rights termination cases than are parents with no disabilities (Kollberg 1989, Watkins 1995, Swain \& Cameron 2003, Booth \& Booth 2004, Sheehan \& Levine 2005).

Although it has been emphasized that parents with intellectual disabilities should not be judged beforehand, their identification as a risk group has warranted their special treatment, which includes the provision of special support and assistance and a certain amount of control (Areschoug 2005). Intellectual disabilities have thus been defined as a risk factor. As such, they constitute one of the factors that we can expect to be taken into considerations in assessments of the parent potential of persons who are not yet parents, but who are aspiring to parenthood.

\section{The Swedish context}

Of special interest in the present paper are the ways in which the best interest of the child is in potential conflict with the best interests of other groups. I argue that the status of the best interest of the child as an argument for state-authorized assessments of parent potential varies 
with the amount of involvement from state authorities that is needed in the process of creating parenthood and that it has changed over time.

Every situation that entails consideration of taking a child into custody harbours a conflict between the rights of parents to integrity and immunity against encroachment by state authorities and the right of the child to societal protection against poor home conditions and maltreatment. The issue of intellectual disability and parenthood is characterized by a further potential conflict: between the right of the intellectually disabled person to integrity and selfdetermination and the obligation of the state to guard citizens who are defined as weak. Belonging to the social categories traditionally regarded as weak, and therefore in need of societal protection, are persons with intellectual disabilities as well as children.

One of the key arguments in the 1960s for providing for the needs of intellectually disabled individuals was the categorization of them as weak and therefore entitled to special support. The need of the weak for support thus became a question of social justice. At the end of the $20^{\text {th }}$ century, the image of individuals with intellectual disabilities as weak was questioned, which illustrates a rhetorical shift in Swedish disability policy towards an aim to downplay differences and difficulties and emphasize similarities between people with and without functional disorders (Gustavsson \& Szönyi 2004).

Such questioning of the traditional image of the intellectually disabled individual as weak was paralleled by an increased emphasis on individual initiative in community care and services. Care and services should be provided on the individual's request only, which means s/he must decide what services s/he requires and then request them. The idea is that individuals with intellectual disabilities should not be treated differently, but in the same manner as all other citizens in need of assistance from society. The support that any individual receives, thus, comes down to her ability to plead her own case before the local authorities. In a system of care and services based on individualized measures and action plans, weakness is 
increasingly regarded as the creation of a well-meaning and paternalistic welfare state (Sandvin \& Söder 1996).

In a way, this shift is paralleled by changes in the view on the status of the child. With the Children and Young Persons Act of 1960, parents were held responsible for their child's care and upbringing, but state authorities were ascribed the duty to intervene if the child's needs were not provided for. Thereby, the relationship between the child and the state was freed, at least in part, from the family, and the status of the child thereby individualized (Näsman 1992).

In the new legislation of 1980 (the Social Services Act and the Care of Young Persons Act), the focus was no longer on the obligations of parents, but on the rights of children. ${ }^{2}$ Child welfare became a more integrated part of social work in general. Further, the importance of treating and supporting the family as a unit in cases of child neglect or abuse meant that children should be separated from their parental homes against the will of their parents only in exceptional cases. The main principle for the work of the social welfare board was now that all interventions should take place in agreement and cooperation with the individual. At the same time, the directions for authority intervention became less specific and the responsibility for child welfare measures more decentralized.

During the 1990s, the status of the biological family has been further reinforced and interventions have been increasingly difficult to motivate (Petersson 2003). The responsibility ascribed to state authorities for children's welfare is less detailed and parental responsibility is increasingly emphasized (Sandin \& Halldén 2003). Simultaneously, as is the case of persons with intellectual disabilities, children are ascribed an increasing amount of competence and the right to self-determination, which brings the question of children's dependence on adult care and protection and thus parental competence to a head (Sandin 2003). 


\section{The best interest of the child vs. the integrity of the family}

In their book on the protection of children, Dingwall, Eekelaar and Murray (1983) identify two standard accounts in the regulation of families in liberal states that produce a sense that accusations of parental failures are grave matters. These accounts emphasize the natural relationship between parent-child and hold that styles of child-rearing should be interpreted as cultural statements and should hence be respected as such. The prevention of the maltreatment of children through family policing in the liberal state thus requires a compromise. The result is a system that neither fully prevents the mistreatment of children nor fully respects family privacy. The balance that is struck between these two poles varies between states and between points in time.

The following account of the public debate on parents with intellectual disabilities at two points in time - the early 1980s and the early 2000s - illustrates a balance shift regarding the status of the family and views on state interventions in family life in the Swedish context.

In an interview published in 1980 in a major Swedish morning paper, a social welfare officer claimed that far too much consideration had been given to the handicap of intellectually disabled parents when the living conditions of their children were evaluated. As a result, the taking of children into custody had been delayed in several cases. She concluded by posing a question: "Is it so important to satisfy these parents' need to have a child that we are willing to sacrifice the children?"3. Hence, she put the best interest of the child in a discursive state of opposition to the needs and wishes of the parents.

At about the same time, a bill introduced to the Parliament raised the issue of protecting children with intellectually disabled parents. The bill demanded from the Parliament a declaration stating "that the child welfare legislation may not discriminate between children of the intellectually disabled and other children". Further, "tolerating poorer protection from society and inadequate living conditions for these children than for children with non- 
disabled parents" was described as unacceptable. ${ }^{4}$ It was also argued that the rights of persons with intellectual disabilities to an independent life could not be defended at the cost of the child's opportunity to grow up in an environment more conducive to normal development. "It now seems as if one sometimes hesitates to intervene and to place these children in foster homes, as this may be perceived as discriminating against the mentally disabled." ${ }^{5}$

The standing committee on social questions recommended rejection of the proposal, but did declare it to be undisputable that children with intellectually disabled parents had the same right as other children to the type of caring and stimulating living environment that was a prerequisite for a child's normal development and to protection against harmful treatment. ${ }^{6}$

In a petition to the minister of Health and Social Affairs in 1980, a social democratic member of parliament described a shift in the debate on intellectually disabled parents. ${ }^{7}$ After "the agitation campaign against social workers who heartlessly took children away from their parents", the media now, according to the MP, accused the authorities of lacking interest and initiative, the consequences being that "defenceless children are left unprotected in bad home environments". She too criticized the special treatment of children with intellectually disabled parents. The difference in treatment that she referred to, however, was not that these children were neglected, but rather that they, to a greater extent than other children, were being watched by the authorities. ${ }^{8}$

In the early 1980s debate on parents with intellectual disabilities, social services were accused of showing too much consideration for the parents at the expense of children's rights to societal protection against detrimental treatment in the parental home. At the beginning of the $2000 \mathrm{~s}$, the situation was different. On the $10^{\text {th }}$ of December 2002, a programme entitled “Too stupid to be a parent?" was broadcast on Swedish television. The programme was about a couple with intellectual disabilities, living in the small town of Oskarshamn, and their young son. According to the facts presented in the programme, the couple was taken to supervised 
housing directly after leaving the maternity hospital for investigation of their ability to manage their role as parents. After a while, the boy was taken into custody. The standpoint conveyed in the programme was that is was wrong to take the boy, as the couple's failings were perceived as trivial. The programme marked the starting point of a wave of concurring articles with headlines such as "I admit, I have shaken the baby's bottle", "The parents, who were rejected" and "Almost rejected as mum".

The programme and many of the subsequent articles were critical of the explanations for why the son of the Oskarshamn couple had been taken into custody. The critique was partly based on the programme's description of the couple's decisive mistakes as being mistakes any parent could have made. However, the critique against social services also included a general questioning of the right of authorities to interfere in family life (Rosenberg 2003). ${ }^{10}$ What was being guarded in the articles was the right of parents to integrity.

The TV programme was also met with critique, most notably in a book by Barbro Hindberg published by The Forum for Children and Youth (Barn- och ungdomsforum) (Hindberg 2003). Hindberg accused the programme, as well as some of the articles that followed it, of disseminating simplified descriptions of reality. According to her, the indignation over taking a child of parents with intellectual disabilities into custody was caused by the Swedish public's bad conscience over the sterilization policy of the inter- to post-war years. Hindberg's interpretation is in part confirmed by a passage in the National Board of Health and Welfare information booklet from 1990: "Considering ... our tradition of coercive measures regarding these parents (parents with intellectual disabilities; my remark), it is necessary to attach great importance to the legal rights of the parents." 11

We will return to the Swedish sterilization policy of the inter- to post war years and the discourse on birth control and women with intellectual disabilities in the last section of this paper. The difference between the assessment of parents with intellectual disabilities and the 
assessments made prior to the sterilization of mainly women in the inter- and post-war years is that whereas the former is an assessment of parent performance the latter is an assessment of parent potential. Although many of the women who were sterilized during that period did have children, many of the young girls who had the same operation did not. In these cases the decisions made regarding the operation were based on an assessment of potential as parents. In the following I will discuss the extent to which the best interest of the child has been used as an argument for state intervention, in assessments of parent potential rather than of parental performance.

\section{Assessment of parent potential - adoption}

Through adoption, families are created with the assistance of the state. Adoption requires legislation, the assistance of local authorities as well as state-authorized adoption agencies. Inter-country adoption also requires the assistance of authorities and the child's representative in a sending country. Through adoption, children are left in the permanent care and charge of persons who are not their birth parents, and persons who perhaps otherwise would have remained childless are assisted in becoming parents. This means that the state has a prominent role in the creation of families through adoption. The fact that, in adoption, the state actively contributes to creating families is precisely what has formed the argument for the state's role as the guarantor of the child's best interests in the adoption process. It also means that the state has the opportunity to supervise and control the adoption process and to select the adoptive parents it finds suitable. Therefore, adoption may be described as a means for the state to create the kind of families it favours (O’Shaugnessy 1994, Modell 2002, Melosh 2002). Because the image of the ideal family is constantly changing, so are the criteria for adoptive families. Historically, these criteria have included marital status, sexual orientation, 
age and ethnicity. In inter-country adoption, these criteria have also been globally negotiated (Howell 2006).

Sweden's first adoption law was passed in 1917. Here, as well as in subsequent adoption laws, it was stipulated that every adoption facilitated and sanctioned by state authorities should be to the benefit or in the best interest of the child. ${ }^{12}$ Adoption involves the matching of an existing child with parents who are not the child's biological parents, but who are regarded as better equipped to care for and raise the child. A prominent part of safeguarding the best interest of the child in the adoption process is the assessment of the fitness of presumptive adoptive parents, for which the Swedish state has assumed responsibility. One significant change in adoption procedures in Sweden is that, whereas in the 1920s assessments of presumptive adoptive parents almost exclusively concerned adoption of foster children, the home studies of the 1970s aimed at assessing applicants for inter-country adoptions. This shift also meant that the assessments were no longer aimed at evaluating the ability of the applying couple to care for a specific child, who perhaps had lived in their home for some time. In inter-country adoption, the child is seldom known at the time of the home study. Hence, what is evaluated is not an existing relationship between a child and her foster parents or the applicants suitability as parents for a particular child, but rather their general capability as parents (Lindgren 2006).

The adoption home study is performed by a social worker and results in a written report. On the basis of this report, the social welfare board decides whether or not to give its consent to the adoption plans of the applicants. Without this consent, the adoption process cannot be continued. According to the guidelines issued by NIA, The Swedish Board on Inter-country Adoption Issues, and as stipulated in the Hague Convention on inter-country adoption, assessments of adoptive parents should include information on previous and current living circumstances, state of health, personality and hobbies, religion/philosophy of life, marriage 
and relations to family and friends, motive for adoption and knowledge and experience of children and young people. According to the recommendations issued by NIA, factors that could lead to the rejection of an adoption applicant included: the age of the applicants, remarks in the police or social registers as well as medical conditions such as diabetes, obesity and disabilities. A disability as such, however, is not claimed to constitute a hindrance to consent to adoption if it does not stand in the way of a normal life, lead to isolation or demand too much assistance from other family members (NIA 1982, p. 13-19; NIA 1997, p. 32-39).

Evidence of the undisputable status of the best interest of the child as the guiding principle in adoptions is that any concerns regarding potential infringement on the integrity of applicants as a result of the home study process are met with references to "the child's right to a good family" and the responsibility of the state to ensure that the adoption be in the best interest of the child (NIA 1982, p. 9; NIA 1997, p. 27). However, it may be the case that acceptance of methods of assessment of presumptive adoptive parents that potentially infringe on their integrity has decreased over time. Several Swedish adoption agencies claim to have observed a tendency, in that home studies reports, made by the social worker, now in many cases contain few actual judgements of the applicants' potential as parents. Instead, many of the reports seem to be based almost entirely on the autobiographies that presumptive adoptive parents are asked to submit at the beginning of the assessment process. ${ }^{13}$

Still, even in the most recent recommendations issued by NIA/MIA, it is emphasized that parenthood and having children do not constitute a general right for adults. Social workers are advised to see themselves as representatives of the child, even if at the time of the home study the child is unknown, rather than as allies of the presumptive adoptive parents (NIA 1982, p. 6; NIA 1986, p. 9; NIA 1997, p. 56; MIA 2006). If the adoption of a child by a certain applicant is not regarded as in the best interest of the child, the adoption plans should 
be stopped by the social worker, however sympathetic s/he might be to the situation of the applicants.

Just as with parental rights termination cases, the adoption process harbours a potential conflict between not only the right of the child and the wishes of (presumptive) parents, but also between the best interest of the child and the rights of minority groups to nondiscrimination. A recent example of such a conflict is the Swedish debate on and parliamentary inquiry into the right of homosexual couples to be assessed as adoptive parents. ${ }^{14}$ Yet another example is the reactions in the media to the recent changes in requirements for presumptive adoptive parents made by the central Chinese adoption authority. The new requirements to be met by adopters include a maximum body mass index of 40, which caused the chairman of the Swedish National Association for the Overweight to argue that such a rule was inconsistent with human rights. ${ }^{15}$ Hence, what he implied was that the new rules discriminated against overweight adoption applicants.

In adoption, the definition of what constitutes the best interest of the child, made by authorities and organizations in sending as well as receiving adoption countries, plays a powerful role. Social workers, agency representatives and several other parties involved in the adoption process function as representatives of the child. As such, it is their responsibility to prevent applicants who do not correspond with their definition of a good parent from adopting the child that they represent. In in-country adoption, they may represent a child who is known to all parties involved in the process at the time of assessment of the applicants. In intercountry adoption, however, the child is often not known to the social worker in the receiving country. In the assessment of applicants, the social worker is thus the representative of an unknown child. In the following section, I will continue by tracing how the best interest of the child has been used as an argument in assessments of parent potential, in situations where the state has appointed itself as the representative of the unborn child. 


\section{Assessment of parent potential - assisted reproduction}

Whereas families created through adoption require the assistance of a state-authorized social worker and adoption agency, families created with the aid of assisted reproduction techniques require the assistance of a doctor at a fertility clinic. The development of new techniques has compelled the state to issue regulations and to decide on the involvement of the public health care system regarding their application. The fact that individuals or couples who have difficulties conceiving a child on their own must seek the assistance of state-authorized clinics makes it possible to regulate who will have access to assisted reproduction techniques. In that respect, state involvement in assisted reproduction resembles state regulation of adoption. The difference is that, in the latter case, a child already exists and the assessment of the presumptive adoptive parents concerns the placement of a child and not the child's coming into existence, as is the case in assessments related to assisted reproduction treatment.

In discourses on assisted reproduction involving gamete donation, the best interest of the child is a recurrent theme in relation to rights to knowledge about biogenetic origin (Lyndon Shanley 2002). As a consequence of the involvement of a third party, the Swedish 1981 Insemination Committee compared donor insemination to adoption with respect to the child's right to knowledge about her biogenetic origin. The committee was led by government appointed Parliamentary Commissioner for the Judiciary and the Civil Administration, Tor Sverne, who had previously led the Commission on Children's Rights. Sverne's previous role as chairman of the Commission on Children's Rights has been ascribed significance for the strong emphasis the Insemination Committee placed on the legal protection of children (Burrell 2005). Mainly, this concern referred to children's right to information on their biogenetic parents, which was used as an argument for the abolishment of donor anonymity. ${ }^{16}$ The main question of concern in this paper, however, is whether the best interest of the child 
is also used as an argument for restricting access to assisted reproduction techniques as a result of assessment of the parent potential of applicants.

In Sweden, the use of assisted reproduction techniques is regulated in the two acts on insemination (1984) and conception outside the body (1988). ${ }^{17}$ The regulations in these two acts imply that assisted reproduction techniques are not available to everybody. For example, to be eligible for donor insemination, a woman has to be married to, cohabit or be in a registered partnership with a man or another woman. ${ }^{18}$ Further, in the preparatory work preceding the 1984 act, a medical assessment of the couple is described as necessary to create the conditions for "a pregnancy that does not jeopardize the future health of the child". ${ }^{19}$ These regulations apply to all assisted reproduction techniques. Explicit references to the best interest of the child, however, are made only in relation to techniques that involve gamete donation. ${ }^{20}$ According to the recommendations issued by the Insemination Committee in 1983 , a prerequisite for donor insemination should be " - as in the case of adoption - that the needs and interests of the prospective child be satisfied and safeguarded". ${ }^{21}$ The subsequent legislation provided that donor insemination should only be performed if "it can be presumed that the prospective child will grow up under good conditions". ${ }^{22}$

To ensure that the couple undergoing reproduction treatment with donated gamete will be able to provide good living conditions for the child, psychological and social assessments in addition to the general medical examination were argued to be necessary. ${ }^{23}$ In part, the necessity of these assessments is motivated with reference to the aforementioned analogy between donor insemination and adoption. The fact that both parents are not the child's biogenetic parents is claimed to make this kind of parenthood more challenging than parenthood in general. As a consequence, the requirements that these parents should meet are claimed to be comparable to those of adoptive parents. ${ }^{24}$ 
The purpose of the medical, psychological and social assessments was further elaborated in guidelines passed by the National Board of Health and Welfare in $2002 .{ }^{25}$ In addition to tests for HIV, hepatitis and venereal diseases, any occurrence of other somatic or psychological illnesses or disabilities should be investigated and assessed by a physician. The aim ascribed to these medical assessments is to assess "the ability of the man as well as of the woman to function as parents throughout the child's whole upbringing". ${ }^{26}$ Concerns for the living conditions of the child are repeated in the motivations for a psychological and social assessment. The purpose of these assessments, according to the directions, is for the physician “to gain insight into the couple's fitness as parents". During the assessment, it should be clarified that both the man and the woman have the ability to care for and raise a child. ${ }^{27}$

The assessments and requirements referred to above apply to assisted reproduction treatment with donated gamete. What role, then, does the best interest of the child play in the regulation of assisted reproduction that does not involve donors? None at all. Pregnancy and parenthood attained through techniques that do not involve donor gamete are regarded as no different than parenthood resulting from naturally occurring conception. ${ }^{28}$ As a consequence, the psychological and social assessments of presumptive parents that are required in assisted reproduction involving the use of donor gamete are seen as unnecessary when treatment does not involve a donor. Although also in this case the state contributes to the creation of parents and children through its regulation of the application of assisted reproduction techniques and the clinics that provide them, it does not claim the right to select couples for treatment as it does in the case of assisted reproduction involving gamete donation. Hence, the state does not aim to guarantee the best interest of the unborn child when the child's parents will also be her/his biogenetic parents. The more naturally occurring parenthood is, the lesser are the explicit ambitions of the state to intervene in the name of the best interest of the child by 
preventing individuals, whose parent potential is assessed as being questionable, from becoming parents.

In the last section of the paper, I will discuss what implications this has for policies regarding parenthood and intellectual disability. Parents with intellectual disabilities are more likely to appear in child protection cases than are parents with no disabilities. They are viewed as a risk group in need of support as well as surveillance. The question that I will pose in the following section, however, concerns individuals with intellectual disabilities as potential parents. How have Swedish policies addressed the potential parenthood of a category of individuals whose handicap is regarded as a risk factor? In doing so, I will first take a step back in time to the Swedish sterilization policies of the inter- to post-war years.

\section{Sterilization and birth control - potential parents with intellectual disabilities}

Perhaps more than any other practice, the sterilization of individuals regarded as intellectually disabled - or feeble-minded, which was the term used during this period - that took place in many countries around the world during the first half of the 20th century is germane to the issue of assessment of parent potential. Decisions regarding sterilization were ultimately based on judgements of the parental unfitness - eugenically or socially - of people who in many cases were not yet parents.

\section{Swedish sterilization policies 1934-1975}

The first sterilization act was passed in Sweden in $1934 .{ }^{29}$ According to this act, sterilizing operations could be performed either on an eugenic indication, i.e. the risk that a person would transmit her hereditary dispositions for mental illness or feeble-mindedness to her offspring, or on a social indication, i.e. the assessment of a person as incapable for all time of caring for her children. 
The act only regulated sterilization of individuals who were judged to lack the legal capacity to give their consent to the operation. As this was seen as an impediment to the application of the law, a new commission was appointed, and in 1941 a second sterilization law was passed. The wording "incapable" of caring for a child was changed to "evidently unfit", which widened the definition of legitimate reasons for sterilization. ${ }^{30}$ During the second half of the 1950s, the number of sterilizations gradually dropped and the percentage of operations concerning individuals classified as "feeble-minded" of the total number of sterilization decreased (Tydén 2002, Runcis 1998). The media reported on scandals, in which persons had been sterilized for what were regarded as the wrong reasons. Although the rights of the individual and a cautious application of the sterilization law were now argued for, the idea that society had an interest in the sterilization of certain individuals was not entirely rejected (Tydén 2002). The sterilization of individuals labelled as intellectually disabled continued to be regarded as advisable also by the parent organization FUB (Föräldraföreningen Utvecklingsstörda Barn), which claimed in an official letter to the Minister of the Interior in 1953 that it was not against the sterilization of intellectually disabled (Tydén 2002).

The sterilization law of 1941 remained unchanged until $1975 .{ }^{31}$ In its 1974 report the sterilization committee suggested that the possibility to sterilize legally incapacitated persons should be retained. The condition was that a court appointed administrator should make the application for the operation on behalf of the person he represented, and that the sterilization was of "substantial benefit" to the person that the application concerned. ${ }^{32}$ The argument for why the committee wanted to retain that possibility in the legislation included the recognition of the right of intellectually disabled persons to a sexual life and the concurring preconception that pregnancy and childbearing should best be avoided for individuals with intellectual disabilities. In this respect, sterilization was claimed to be the birth control technique best 
suited for them. ${ }^{33}$ In the bill, however, the possibility of sterilization of legally incapacitated persons was revoked. Since then, sterilizing operations may be performed only on the request of the patient her-/himself, which implies that individuals who are judged to lack the intellectual capacity to make such a decision cannot undergo sterilizing operations. In practice, this means that, for a large proportion of intellectually disabled, sterilization is not a possibility.

Despite this change in the legislation, the door on sterilization was not entirely closed in the subsequent debate. In a publication by the National Board of Health and Welfare in 1980, sterilization was described as a sensitive issue indeed, but it was not considered unlikely that the negative attitude towards sterilization prevailing among staff as well as the intellectually disabled themselves would come to change. ${ }^{34}$ Seven years later, in 1987 , the issue was raised again in a motion to the parliament with references to the assumed difficulties of intellectually disabled women to use other birth control techniques. Sterilization, it was claimed, would provide the most efficient protection against pregnancy for these women. ${ }^{35}$

The continued debate on sterilization of the intellectually disabled in the 1970s and later indicates two things of interest for the present analysis: 1) Although involuntary sterilization as such was no longer seen as acceptable, the preconception that pregnancy and childbearing ideally should be avoided for women with intellectual disabilities continued to prevail. 2) Whereas the focus in the 1930s and 40s was on the genetic status of the population and concern for the well-being and life expectancies of the unborn child, the explicit concern in the debate on sterilization of the intellectually disabled in the 1970s and later was directed towards the women themselves. 


\section{Unwanted parenthood}

The National Board of Health and Welfare continued to issue recommendations for persons with intellectual disabilities to refrain from having children in 1975,1980 and $1990 .{ }^{36}$ In the publication from 1990, this was motivated in the following way. There is "great agreement in the care sector that individuals in need of substantial special care ought not to be parents out of consideration for the children as well as themselves"37

What distinguishes the quotation from 1990 from the wordings of the two previous publications is the way in which it defines the group of individuals who ought to be advised against becoming parents. While the publications from 1975 and 1980 spoke of "mentally disabled" (utvecklingsstörda), the quotation from 1990 referred to "those who are in need of substantial special care" (de som är i behov av omfattande särskilda omsorger). In this way, the advice against parenthood was linked to the need for assistance rather than to the intellectual disability itself.

One of the circumstances continuously used to portray intellectually disabled women's childbearing as problematic concerned the reasons these women were claimed to have for wanting a child. Weekly magazines were accused of displaying a one-sided account of happy adult life, and women with intellectual disabilities were claimed to be easily duped into believing that having a child was the only way to happiness. ${ }^{38}$ The discursive effect of this is twofold. The image of parenthood as a necessary part of adult life is presented as a myth, rendering less severe the appeal for intellectually disabled individuals to refrain from parenthood. Further, the wish of intellectually disabled women to have a child was portrayed as a desire based on false notions of a happy adult life. Also, many women with intellectual disabilities were said to want a child because of the expectation that a child would improve their status and offer acknowledgement from those around them. For these women, 
parenthood was claimed to be about gaining a sense of self-worth by making the scope of their own helplessness appear less significant in relation to that of a child..$^{39}$

The explanations for why intellectually disabled women want a child were, thus, mainly sought in what were described as various kinds of fallacies and delusions, i.e., an unrealistic notion of what it is like to take care of a child, the idea that a happy adult life must include parenthood and that a child would make her own need for assistance seem less significant. Together with the recommendations to refrain from having children, this defined the intellectually disabled as a group of undesirable parents.

The view on intellectually disabled persons' childbearing as problematic, thus, continued to prevail throughout the late $20^{\text {th }}$ century. The question is what the recommended precautions were and how they were motivated. The National Board of Health and Welfare information booklet from 1980 defined two preventive tasks for social services in respect to intellectually disabled women's childbearing: to "prevent children from being harmed" and to "prevent a mentally disabled woman from having a child she lacks the ability to take good care of' ${ }^{40}$ The question addressed in the following is how the latter of these preventive measures was argued for.

\section{Voluntary birth control}

The explanations for the change in the implementation of and debate on sterilization policy can be sought in the changed attitude towards persons with intellectual disabilities and the rights ascribed to them (Tydén 2002). At the end of the 1960s, Bengt Nirje put into words the so-called normalization principle, according to which individuals with intellectual disabilities were entitled to the same living conditions as the population in general (Nirje 1969). One of the claims of this principle was that intellectually disabled persons were entitled to noninstitutional housing, which would increase their opportunities to have social contacts, 
encounters with members of the opposite sex, relationships and a sexual life. The opportunity to develop, satisfy and find pleasure in one's sexuality was now described as a right for adults with intellectual disabilities (Katz 1975).

An equally important factor for the change in application of the legislation on sterilization and subsequently its abolition was, of course, the introduction of new birth control techniques during the 1960s (the pill in 1964 and the IUD in 1966). Although the effects of these techniques were not irreversible, like those of a sterilizing operation, their objective was to prevent pregnancies and childbearing. As such, the recommendations issued for women with intellectual disabilities to use means of birth control needed to be motivated.

In the 1975 publication from the National Board of Health and Welfare, the argumentation for why an abortion might be advisable for a pregnant woman with intellectual disabilities comprises an account of the risk that is claimed to be at hand. "The situation often becomes difficult for a mentally disabled woman when she expects a child, regardless of whether or not she is married. An abortion might be advisable.” (Katz 1975, p. 36). The risk referred to, thus, concerned the life and well-being of the woman, which means that abortion and birth control could be argued for in terms of her best interest.

Officially, the use of coercion with regard to birth control ceased to be acceptable with the abolishment of the sterilization laws. An interesting question, therefore, is how the acceptable modes of procedure for birth control for the intellectually disabled have been worded and launched during the latter part of the $20^{\text {th }}$ century. The recommendations of the National Board of Health and Welfare regarding birth control for the intellectually disabled from 1980 illustrate how the dividing line between acceptable and unacceptable means was worded. "The fundamental principle in guidance on contraceptives is the issue of motivation. One may not force, command, persuade or coax people to use contraceptives. What you may do is help them find reasons to protect themselves." ${ }^{, 41}$ By describing the value of birth control 
as something that persons with intellectual disabilities ought to receive assistance in comprehending, birth control as such was represented as a benefit - something of use to the individual. Further, the word "help" signals differentiation from such modes of procedure as to "force, command, persuade or coax" somebody to use contraceptives.

In the National Board of Health and Welfare information booklet from 1990, the word "support” (stöd) has a similar effect. Many individuals with intellectual disabilities were claimed to "receive support in using contraceptives" (p. 7, my italics). Further, in cases where a pregnancy had been revealed, it was recommended that "the woman should receive support in deciding whether she wants to give birth to the child or have an abortion" (p. 24, my italics). ${ }^{42}$

Giving someone support in using contraceptives or in considering an abortion implies that the person in question benefits from these measures. The main argument for the prevention of intellectually disabled women's pregnancies and childbearing, thus, seems to have become consideration of the well-being and future life of the woman. The best interest of the child and concern for the well-being and life expectancies of the unborn child, on the other hand, did not constitute an argument used for birth control in women with intellectual disabilities after the 1960s.

\section{Conclusion}

The best interest of the child as an argument for state intervention in family life competes with other principles - most notably arguments that emphasize the right of the family to integrity and freedom from state encroachment. For the most part, these arguments refer to existing families. The varying status of the best interest of the child as an argument in state interventions regarding parents with intellectual disabilities can be traced through media reactions to the actions of social services and the political debate at two points in time. Social 
services have either been accused of neglecting the right of children to protection against harmful treatment while trying to downplay the significance of the disabilities of the parents, or of intervening in family life too readily. In the latter case, the critique against social services included a general questioning of the right of authorities to interfere in family life.

Whereas these state interventions concerned existing families and were based on assessments of parental performance, the assessments made in adoption, in assisted reproduction treatment and in relation to sexually active women with intellectual disabilities are assessments of parent potential. These three different paths to parenthood depend to varying degrees on state-authorized assistance. Thereby, they also facilitate to varying degrees assessments of parent potential and state regulations of parenthood.

The status of the best interest of the child, as legitimization of state-authorized assessment of the parent potential of men and women who are aspiring to parenthood, varies with the degree of assistance that is needed for them to become parents. In adoption, where the role of the state is paramount for the creation of parenthood, the best interest of the child as an argument surpasses all other interests. The state and its authorities have taken it upon themselves to safeguard the best interest of the child in every adoption. Most notably, this means preventing men and women who are regarded as lacking parenting qualities from becoming parents. Because intellectually disabled parents are viewed as a risk group, it is not surprising that intellectual disabilities are regarded as a risk factor. This means that applicants with intellectual disabilities can be denied consent to adopt a child based on an assessment of their potential as parents as deficient. The same is true for assessment preceding assisted reproduction treatment with donor gamete.

According to the recommendations issued by the National Board of Health and Welfare, the needs and interests of the prospective child should be satisfied and safeguarded in decisions regarding donor-aided assisted reproduction. This includes the potential refusal of 
access to assisted reproduction techniques to couples regarded as unfit parents on the basis of a medical, psychological and social assessment. When parenthood comes into existence at a fertility clinic, but without the aid of donor gamete or without the assistance of state authorities at all, no state-initiated assessments of the parent potential of the individuals aspiring to parenthood take place. In these cases, the state does not claim the role of guarantor of the best interest of the child. This means that the state claims the right to prevent parenthood - and, in the case of assisted reproduction, children - from coming into existence in the name of the best interest of the child only if it contributes to creating families in which there are no or only partial biogenetic links between parents and child. It also means that the state and its authorities do not intervene to prevent a biogenetically related family from coming into existence even if the presumptive parents belong to a risk group.

This does not mean, however, that the parenthood of individuals with intellectual disabilities is not viewed as something problematic, which is evident from the many recommendations concerning how women with intellectual disabilities should be convinced to refrain from having children and supported in using contraceptives. The explicit motive in these recommendations, however, is not the best interest of the child, but rather the best interest of the woman herself. 


\section{Notes}

${ }^{1}$ See for example the American Fourteenth Amendment's Due Process Clause.

${ }^{2}$ SFS 1980:620, SFS 1980:621.

${ }^{3}$ Dagens Nyheter 800123.

${ }^{4}$ Motion 1979/80:1657.

${ }^{5}$ Motion 1979/80:1657.

${ }^{6}$ Socialutskottets protokoll 1979/80:44.

${ }^{7}$ Riksdagsprotokoll 1979/80:134, fråga 193.

${ }^{8}$ Riksdagsprotokoll 1979/80:134, fråga 193. See also SOU 1981:26.

${ }^{9}$ Aftonbladet 021213, Aftonbladet 021220, Dagens Nyheter 021220.

${ }^{10}$ Dagens Nyheter 030113.

${ }^{11}$ SoS-rapport 1990:24, p. 27.

${ }^{12}$ SFS 1917:378, SFS 1944:180, SFS 1958:637, 640, SFS 1971:796. For a discussion of Swedish adoption legislation and policy 1920-1970, see Cecilia Lindgren (2006).

${ }^{13}$ SOU 2003:49, p. 222-223.

${ }^{14}$ SOU 2001:10.

${ }^{15}$ Aftonbladet 061220.

${ }^{16}$ SOU 1983:42, p. 203-204.

${ }^{17}$ SFS 1984:1140, SFS 1988:711.

${ }^{18}$ SFS 1984:1140 §1, SFS 2005:443, SFS 1988:711 3§, SFS 2005:445.

${ }^{19}$ SOU 1983:42, p. 81, 86 .

${ }^{20}$ SFS 2002:252. The use of eggs from a donor became legal in Sweden with the implementation of this act in 2003.

${ }^{21}$ SOU 1983:42, p. 204.

${ }^{22}$ SFS 1984:1140 3§, SFS 1988:711 $5 \S$.

${ }^{23}$ SFS 1984:1140 3§, SFS 1988:711 5§.

${ }^{24}$ SOU 1983:42, p. 85-86.

${ }^{25}$ SOSFS 2002:13 4 kap.

${ }^{26}$ SOSFS 2002:13 4 kap.

${ }^{27}$ SOSFS 2002:13 4 kap.

${ }^{28}$ SOU 1983:42, p. 81, 86.

${ }^{29}$ SFS 1934:17.

${ }^{30}$ SFS 1941:282..

${ }^{31}$ SFS 1975:580.

${ }^{32}$ SOU 1974:25, p. 14.

${ }^{33}$ SOU 1974:25, p. 91.

${ }^{34}$ Socialstyrelsen anser 1980:6, p. 14-15.

${ }^{35}$ Riksdagstrycket 1986/87, protokoll 83 fråga 424 M. Karlsson (c) till socialministern; protokoll 90, s. 42-43.

${ }^{36}$ G. Katz (1975), p. 25; Socialstyrelsen anser 1980:6, p. 3; SoS-rapport 1990:24, p. 8, see also p. 25.

${ }^{37}$ SoS-rapport 1990:24, p. 8.

${ }^{38}$ G. Katz (1975), SOU 1981:26.

${ }^{39}$ Socialstyrelsen anser 1980:6, p. 14.

${ }^{40}$ Socialstyrelsen anser 1980:6, p. 38.

${ }^{41}$ Socialstyrelsen anser 1980:6, p. 14-15.

${ }^{42}$ SoS-rapport 1990:24. 


\section{References}

Aftonbladet 021213 "Jag erkänner, jag har skakat vällingflaskan" [I admit, I have shaken the baby's bottle] by L. Marklund.

Aftonbladet 021220 "Föräldrarna som blev underkända" [The parents who were failed] by P. Kadhammar.

Aftonbladet 061220 "Överviktiga får inte adoptera från Kina" [Overweight are not allowed to adopt from China] by J. Melén.

Booth, W. \& T. Booth (2004) "A family at risk. Multiple perspectives on parenting and child protection”, British Journal of Learning Disabilities 32: 9-15.

Burrell, Riitta (2006) Assisted Reproduction in the Nordic Countries. A comparative study of policies and regulations. Copenhagen, Nordic Committee on Bioetics.

Dagens Nyheter 800123. Interview with Anitha Rönström by B. Jöberger.

Dagens Nyheter 021220. "Nästan ratad som mamma" [Almost rejected as mum] by G. Svensson.

Dagens Nyheter 030113. "Hur odugliga föräldrar ska vi tåla?" [How incompetent parents shall we tolerate?] by G. Rosenberg.

Donzelot, J. (1980) The Policing of Families. London, Hutchinson.

Gustavsson, A. \& Szönyi, K. (2004) "Globala begrepp och lokala innebörder" [Global concepts and local meanings] p 103-118. In Anders Gustavsson (Ed.) Delaktighetens språk [The language of participation]. Stockholm, Studentlitteratur.

Hindberg, B. (2003) Barn till föräldrar med utvecklingsstörning [Children of parents with intellectual disabilities]. Stockholm, Gothia.

Howell, S. (2006) The Kinning of Foreigners. Transnational Adoption in a Global Perspective. New York \& Oxford, Berghahn Books.

Katz, G. (1975) Samlevnads- och sexualfrågor hos psykiskt utvecklingsstörda [Questions concerning life together and sexuality in relation to the mentally disabled]. Stockholm, Svenska församlingen för psykisk hälsovård.

Kollberg, Evy (1989) Omstridda mödrar. En studie av mödrar som förtecknats som förståndshandikappade. [Disputed mothers. A study on mothers labeled as developmentally disabled] Gothenburg, Nordiska hälsovårdshögskolan.

Lindgren, Cecilia (2006) En riktig familj. Adoption, föräldraskap och barnets bästa 19271975. (diss.) [A real family. Adoption, parenthood and the best interest of the child 1917-1975] Stockholm, Carlsson bokförlag.

Lyndon Shanley, Mary (2002) "Collaboration and Commodification in Assisted Procreation: Reflections on an Open Market and Anonymous Donation in Human Sperm and Eggs", Law \& Society Review 36: 257-284.

Motion 1979/80:1657 om skyddet för barn till utvecklingsstörda föräldrar [Parliamentary bill on the protection for children of mentally disabled parents].

Melosh, B. (2002) Strangers and kin. The American way of adoption. Cambridge, Mass., Harvard University Press.

Modell, J. (2002) A sealed and secret kinship. The culture of policies and pravtices in American adoption. New York, Berghahn Books.

MIA (2006) Så går det till att adoptera [To adopt] Stockholm, MIA.

NIA (1982) Internationella adoptioner. Handbok för socialnämnder. [International adoptions. Handbook for social welfare boards] Stockholm, NIA. 
NIA (1986) Internationella adoptioner. Handbok för socialnämnder (reviderad utgåva) [International adoptions. Handbook for social welfare boards] Stockholm, NIA.

NIA (1997) Internationella adoptioner. Handbok för socialnämnder (reviderad utgåva) [International adoptions. Handbook for social welfare boards] Stockholm, NIA.

Nirje, B. (1969) "Normaliseringsprincipen och dess innebörd för omsorgerna om de utvecklingsstörda" [The normalization principle and its meaning for care and services for the mentally disabled], Psykisk utvecklingshämning 1:1-9.

Näsman, Elisabet (1992) Individualization and institutionalization of childhood in presentday Europe. Stockholm, Stockholms universitet.

O'Shaughnessy, T. (1994) Adoption, social work and social theory. Making the connections. Aldershot, Avebury.

Petersson, G. (2003) "Med hänsyn till barnets vilja? Socialtjänstlagens barnsperspektiv och den nya välfärdsstatens villkor" [With regard to the will of the child? The child perspective of the Social Servies Act and the conditions of the new welfare state]. $p$ 139-176. In Sandin, B. \& Halldén, G. (Eds.) Barnets bästa. En antologi om barndomens innebörder och välfärdens organisering [The best interest of the child. An anthology on the meanings of childhood and the organisation of welfare]. Stockholm, Symposium.

Riksdagsprotokoll 1979/80:134, fråga 193 tillsocialministern om den sociala omsorgen om vissa barn [Parliamentary protocol, question to the Minister of Health and Social Affairs on the social care for certain children].

Riksdagstrycket 1986/87:83 fråga 424 M. Karlsson (c) till socialministern [Parliamentary publication, question to the Minister of Health and Social Affairs].

Runcis, M. (1998) Steriliseringar i folkhemmet [Sterilizations in the people's home] (diss.) Stockholm, Ordfront.

Sandin, B. (2003) "Barndomens omvandling - från särart till likart" p 221-240. In Sandin, B. \& Halldén, G. (Eds.) Barnets bästa. En antologi om barndomens innebörder och välfärdens organisering [The best interest of the child. An anthology on the meanings of childhood and the organisation of welfare]. Stockholm, Symposion.

Sandin, B. \& G. Halldén (2003) "Välfärdsstatens omvandling och en ny barndom" p 7-24. In Sandin, B. \& Halldén, G. (Eds.) Barnets bästa. En antologi om barndomens innebörder och välfärdens organisering [The best interest of the child. An anthology on the meanings of childhood and the organisation of welfare]. Stockholm, Symposium.

Sandvin, T. J. \& Söder M. (1996) "Welfare state reconstruction" p 107-119. In Tøssebro, J., Gustavsson, A. \& Dyrendahl, G. (Eds.) Intellectual disabilities in the Nordic Welfare States. Policies and Everyday Life. Kristiansand, Høyskoleforlaget.

SFS 1917:378 Lag om adoption. [Adoption Act]

SFS 1934:17 Lag om sterilisering av vissa sinnessjuka, sinnesslöa eller andra som lida av rubbad själsverksamhet. [Act on sterilization of the mentally ill, the feeble-minded and others with disturbed mental development]

SFS 1941:282 Lag om sterilisering. [Act on Sterilization]

SFS 1944:180 Lag om ändrad lydelse av Lag om adoption 1917:378. [Revision of the Adoption Act]

SFS 1958:637 ̈̈rvdabalk. [Inheritance code]

SFS 1958:640 Lag om ändring i föräldrabalken. [Revision of the Children and Parents Code]

SFS 1971:796 Lag om internationella rättsförhållanden rörande adoption. [Act on international legal relations concerning adoption]

SFS 1975:580 Steriliseringslag. [Sterilization Act]

SFS 1980:620 Socialtjänstlagen. [Social Welfare Act] 
SFS 1980:621 Lagen med särskilda bestämmelser om vård av unga. [Children and Young persons Act]

SFS 1984:1140 Lag om insemination. [Insemination Act]

SFS 1988:711 Lag om befruktning utanför kroppen. [Act on conception outside the body]

SFS 2002:252 Lag om ändring i lagen (1988:711) om befruktning utanför kroppen. [Revision of the Act on conception outside the body]

SFS 2005:443 Lag om ändring i lagen (1984:1140) om insemination. [Revision of the Insemination Act]

SFS 2005:445 Lag om ändring i lagen (1988:711) om befruktning utanför kroppen. [Revision of the Act on conception outside the body]

Sheehan, R. \& G. Levine (2005) "Parents with Mental Illness. Decision-making in Australian Children's Court Cases Involving Parents with Mental Health Problems", The Journal of Social Welfare and Family Law 27: 17-30.

Socialstyrelsen anser 1980:6. Utvecklingsstörda och föräldraskap [The mentally disabled and parenthood].

Socialutskottets protokoll 1979/80:44 [Protocol of the standing committee on social questions].

SOSFS 2002:13 Socialstyrelsens föreskrifter och allmänna råd om assisterad befruktning. [Directions and recommendations of the National Board of Health and Welfare on assisted reproduction]

SoS-rapport 1990:24. Föräldrar med nedsatt begåvning och deras barn [Parents with impaired intellectual abilities and their children].

SOU 1974:25 Fri sterilisering. Betänkande av steriliseringsutredningen. [Free sterilization. Report of the sterilization committee]

SOU 1981:26 Omsorger om vissa handikappade. Betänkande av omsorgsutredningen [Care and services for certain handicap groups. Report of the care and services committee]

SOU 1983:42 Barn genom insemination. Betänkande av Inseminationsutredningen. [Children by insemination. Report of the insemination committee]

SOU 2001:10 Barn i homosexuella familjer. Betänkande av Kommittén om barn i homosexuella familjer. [Children in homosexual families. Report of the committee on children in homosexual families]

SOU 2003:49 Adoption till vilket pris? Betänkande från Utredningen om internationella adoptioner. [Adoption - at what price? Report of the committee on international adoptions]

Swain, P. A. \& N. Cameron (2003) "Good Enough Parenting: Parental Disability and Child Protection", Disability and Society 18: 165-178.

Tydén, M. (2002) Från politik till praktik. De svenska steriliseringslagarna 1935-1975 [From policy to practice. The Swedish sterilization laws 1935-1975]. Stockholm, Acta Universitatis Stockholmiensis.

Watkins, C. (1995) "Beyond status. The American with Disabilities Act and the parental rights of people labeled developmentally disabled or mentally retarded, California Law Review 83: 1415-14175. 